\title{
Pernambuco, Rio da Prata e a crise do Antigo Regime na América ibérica: o "caso" de Félix José Tavares Lira
}

\author{
Pernambuco, Rio de la Plata and the crisis of Ancién \\ Regime: the "affair" of Félix José Tavares Lira
}

\author{
Luiz Geraldo Silva* \\ João Paulo G. Pimenta**
}

Resumo: Este artigo analisa conexões entre a política de Pernambuco e do Rio da Prata, por volta do ano de 1817, por meio de um personagem específico: Félix José Tavares de Lira. Em termos mais gerais, trata-se de propor bases analíticas para a compreensão das relações entre os mundos luso e hispânico no contexto ampliado da crise do Antigo Regime na América ibérica.

Palavras-chave: Pernambuco, Rio da Prata, Independências

Abstract: The aim of this article is to discuss conexions between Pernambuco and Río de la Plata around the year 1817. In a more general sense, it offers a large pattern of comprehension of the indepdendences of Luso and Spanish America in terms of its mutual relationships.

Keywords: Pernambuco, Río de la Plata, Independences

\section{Introdução}

Em sua edição de maio de 1817, o Correio Braziliense, de Hipólito José da Costa, noticiava acontecimentos relativos à eclosão de uma "revolução no Brasil", a qual se iniciara pouco antes "na província de Pernambuco", estendendo-se em seguida "às seis províncias vizinhas do Rio Grande, Paraíba, Ceará, Maranhão, Tamaracá [sic] e

\footnotetext{
* Departamento de História da UFPR/CNPq. E-mail: <lgeraldo@ufpr.br>.

** Departamento de História da USP. E-mail: <jgarrido@usp.br>.
} 
Pará". ${ }^{1}$ Na edição seguinte, de junho de 1817 , o publicista retificava suas impressões iniciais, afirmando que sua "ansiedade" tinha "em grande parte diminuído", uma vez que, agora, era possível "averiguar a extensão do mal" graças aos "numerosos documentos" que lhe chegavam às mãos. "Sabemos", continuava, "que a insurreição se limita a Pernambuco, Paraíba e Rio Grande do Norte". ${ }^{2}$ Na verdade, nos dias em que Hipólito da Costa escrevia seu segundo artigo sobre o tema, a "Revolução de Pernambuco" já tinha sido inteiramente sufocada: desde o dia 20 de maio que bandeiras realistas voltaram a ser hasteadas nas regiões rebeladas, e a 29 de junho, um novo governador nomeado pelo príncipe regente D. João, Luís do Rego Barreto, desembarcara no Recife para levar a efeito prisões e administração de castigos físicos aos réus de lesa-majestade. ${ }^{3}$

Embora refreasse seu assombro, o editor do Correio Braziliense avaliava que o "sucesso em Pernambuco" era "de muito maior importância em suas consequências do que na sua atual extensão". Com efeito, a Revolução de 1817, como hoje bem sabemos, traria impactos consideráveis não às províncias adjacentes a Pernambuco, mas a toda ordem política portuguesa, desdobrados de muitas maneiras pelos anos a ela subsequentes, inclusive no tocante à criação de condições para a ruptura entre Portugal e Brasil, e para o estabelecimento de limites à configuração do próprio Império do Brasil. ${ }^{4}$ Não à toa, além de Pernambuco, outras províncias que Hipólito da Costa imaginara rebeladas em 1817 - "Rio Grande, Paraíba, Ceará, Maranhão... e Pará" - foram algumas das que, junto com Bahia e Cisplatina, mais resistiram à centralização política pretendida pelo Rio de Janeiro a partir de $1822 .{ }^{5}$ Em reconhecimento ao peso e importância do rompimento

Correio Braziliense, maio de 1817, p. 552-553.

Correio Braziliense, junho de 1817, p. 671.

3 LEITE, Glacyra L. Pernambuco, 1817. Estrutura e comportamentos sociais. Recife: Editora Massagana, 1988, p. 236-237. Sobre as posições de Hipólito da Costa acerca do movimento de 1817: FERNANDES, Ana Cláudia. Revolução em pauta. O debate Correio Braziliense-Correo del Orinoco. São Paulo: FFLCH-USP, 2010 (mestrado).

4 BERNARDES, Denis de Mendonça. O patriotismo constitucional. Pernambuco, 18201822. São Paulo/Recife: HUCITEC/Editora UFPE, 2006; BERBEL, Márcia Regina. $A$ nação como artefato. Deputados do Brasil nas cortes portuguesas (1821-1822). São Paulo: Hucitec/FAPESP, 1999, pp. 40-43, 58-65; PIMENTA, João Paulo G. O Brasil e a América espanhola. (Tese de Doutorado). São Paulo: FFLCH/USP, 2003, p. 290.

5 SILVA, Luiz Geraldo. Um projeto para a nação. Tensões e intenções políticas nas "Províncias do Norte". Revista de História (USP), v. 158, p. 199-216, 2008; SOUSA, Maria Aparecida S. de. Bahia: de capitania a província, 1808-1823. São Paulo: FFLCH-USP, 2008 (doutorado); e MACHADO, André R. de A. A quebra da mola real as sociedades: a crise política do Antigo Regime português na província do Grão-Pará (1821-1825). São Paulo: HUCITEC/FAPESP, 2010. 
esboçado no interior do Reino Unido português em 1817, Hipólito da Costa trazia aos seus leitores, na mesma edição de junho daquele ano, outras informações, das quais duas merecem destaque. A primeira, dizia respeito à forma republicana adotada pelos rebeldes e, por conseguinte, ao seu repúdio pela monarquia:

Uma vez que as revoluções começam pelo povo, a tendência é sempre para a forma de Governo Republicano, por mais imprópria que esta seja; por isso que as aparências de democracia são [as] que mais lisonjeiam os indivíduos das classes mais numerosas. Assim, os insurgentes, em vez de seguirem o conselho de seus mesmos membros, que propunham mandar uma Deputação ao Soberano, resolveram logo declarar-se em Estado independente; publicaram o manifesto aonde, em vez de argumentos, só usaram de invectivas diretas contra a pessoa do mesmo Soberano: decretaram o tratamento geral de "Vós", como prova de seu espírito republicano, e começaram a tomar as muitas medidas [...] pelas quais se dispuseram a manter com a força a sua independência. ${ }^{6}$

Já notamos anteriormente como o vago republicanismo pernambucano expresso em 1817, assim como a formação de uma junta de governo, foram aspectos bem observados em conjunto pelas autoridades portuguesas da época, ambos diretamente associados à "realidade política da América espanhola, geralmente referida por vocábulos de conotação negativa". ${ }^{7}$ Tendo isso em mente, a segunda informação de Hipólito da Costa a merecer destaque era relativa à percepção, conforme a qual os líderes daquele movimento

Nomearam, em consequência, um Agente Diplomático, que partiu logo a tratar com o Governo dos Estados Unidos. Este Agente, cujo nome é Antonio Gonçalves da Cruz, chegou a Boston em um navio com bandeira do Governo insurgente, e logo saíram dali vasos de negociantes especuladores, que levaram a Pernambuco mantimentos e munições de guerra. Ao mesmo tempo, expediram os Insurgentes outro Agente (cujo nome é Felix José Tavares de Lima) para Buenos Aires, a fim de tratar também com o Governo Insurgente do Paraguai. ${ }^{8}$

Notam-se, nessas duas informações, dois aspectos entrelaçados. $\mathrm{O}$ primeiro é o peso conferido à experiência política norte-americana

6 Correio Braziliense, junho de 1817, p. 674.

7 PIMENTA, João Paulo G. A política hispano-americana e o império português (18101817): vocabulário político e conjuntura. In: JANCSÓ, István (Org.). Brasil: formação do Estado e da nação. São Paulo/Ijuí, Hucitec/FAPESP/Editora Unijuí, 2003, p. 133.

8 Correio Braziliense, junho de 1817, p.674. 
que, para os revolucionários de 1817, ainda era recente. Com efeito, este aspecto tem sido reiterado pela historiografia décadas a fio. Conforme esta, as idéias políticas alimentadas nos Estados Unidos - mormente o "federalismo" presente naquele movimento - teriam constituído uma das principais, senão a principal, fonte de inspiração programática para os revolucionários de Pernambuco, Paraíba, Rio Grande do Norte e Ceará. ${ }^{9}$ O segundo aspecto, por outro lado, costuma ser muito pouco observado: como as práticas políticas então vigentes na América espanhola - talvez especialmente aquelas que envolviam os territórios do antigo ViceReino do Rio da Prata - representaram, por proximidades espaciais e temporais, bem como por suas molduras institucionais, outro importante modelo, quiçá mais vivo e efetivo, para os rebeldes luso-americanos.

É verdade que os próprios rebelados em Pernambuco e adjacências demonstravam, graças a sua indisfarçável intenção de aproximar-se da América do Norte, grande interesse na experiência histórica dos Estados Unidos, da qual resultara, ademais, a formação de uma ordem política já consolidada em 1817, e que se revestia de modelar caráter civilizacional para muitos agentes políticos ocidentais daquela época. Quadro bem diferente, por outro lado, era o do Rio da Prata, cuja instabilidade e transitoriedade de formas políticas ainda impediam qualquer concepção similar. No entanto, mesmo assim, parece que também o Rio da Prata interessava aos revolucionários pernambucanos. Qual a procedência e os significados desse interesse, até o momento, praticamente ignorados pela historiografia?

Sustentamos que o que se passava na América espanhola se constituía em laboratório fundamental para tais sujeitos históricos, fornecendo-lhes lições, paradigmas e modelos políticos capazes de subsidiar o desenvolvimento de seus próprios projetos - neste caso, precisamente, o de formação de uma junta de governo republicana em Pernambuco. ${ }^{10}$ Não se trata, evidentemente, de negar o peso de um conjunto de outras "experiências" políticas na criação das condições de emergência da contestação em 1817. Muito pelo contrário; trata-se, isto

9 MELLO, Evaldo Cabral de. Frei Caneca ou a outra Independência. In: CANECA, Frei do Amor Divino. Frei do Amor Divino Caneca (organização e introdução de Evaldo Cabral de Mello). São Paulo: Editora 34, 2001, p. 31-32; MELLO, Evaldo Cabral de. A outra independência. O federalismo pernambucano de 1817 a 1824. Rio de Janeiro: Editora 34, 2004, p. 46-49; BERNARDES, Denis A. de M. Pernambuco e o Império (1822-1824): sem constituição soberana não há união. In: JANCSÓ, István (Org.). Brasil: formação do Estado ..., p. 247-248; LEITE, G. L. Pernambuco..., p. 192-200.

${ }^{10}$ SILVA, Luiz Geraldo. 'Pernambucanos, sois portugueses!' Natureza e modelos políticos das revoluções de 1817 e 1824. Almanack Braziliense v. 1, 2005, p. 67-79. 
sim, de considerar que eventos como as revoluções anglo-americana, francesa e haitiana, bem como a crise política das monarquias ibéricas entre 1807 e 1808, e, no caso particular do mundo hispânico, a formação de juntas de governo, o advento do constitucionalismo moderno e os ensaios de quebra violenta da ordem tradicional, dizem respeito, todos eles em conjunto e de maneira variável, ao que se passava também no mundo português; principalmente no Brasil. De que modo isso se deu? Como é possível conferir concretude a necessárias mediações entre o contexto revolucionário mundial e aquele que se desenhava em Pernambuco em $1817 ?^{11}$

Nosso objetivo reside, justamente, em lançar alguma luz sobre essas questões, a partir do "caso" daquele indivíduo que, segundo o Correio Braziliense, teria sido o enviado da junta revolucionária de Pernambuco ao Rio da Prata. Um caso, como veremos a seguir, permeado de equívocos e carregado de significados.

\section{O "enviado" ao Rio Prata}

Em 1817, o antigo Vice-Reino do Rio da Prata era um mosaico de regiões distintas, todas elas gravitando em torno de uma dinâmica vida política permeada de embates, tensões e incertezas no tocante à possibilidade de consecução do projeto que, gravitando em torno de Buenos Aires, mostrava-se como o mais abrangente e por ventura capaz de desembocar na consolidação de uma nova ordem, em substituição ao realismo espanhol. Mesmo porque, no ano anterior, um congresso das antigas províncias do Vice-Reino já declara a independência daqueles territórios. ${ }^{12}$ Este era um ambiente notadamente afeito a formas republicanas de governo, não obstante as monárquicas não serem, em absoluto, dele ausentes; um ambiente, portanto, capaz de interessar aos rebeldes de uma província do Brasil que ademais, como é sabido, tinha

${ }^{11}$ PIMENTA, João Paulo G. O Brasil e a América espanhola..., p. 228-229.

${ }^{12}$ Algumas referências recentes, dentre a vasta bibliografia a respeito, são: GOLDMAN, Noemi (dir.). Revolución, república, confederación (1806-1852). Buenos Aires: Sudamericana, 1998; DI MEGLIO, Gabriel. ;Viva el bajo pueblo! La plebe urbana de Buenos Aires y la política entre la revolución de mayo y el rosismo. Buenos Aires: Prometeo, 2006; VERDO, Geneviève. L'indépendance argentine entre cites et nation (1808-1821). Paris: Publications de la Sorbonne, 2006; MYERS, Jorge. A revolução de independência no Rio da Prata e as origens da nacionalidade argentina. In: PAMPLONA, Marco \& MÄDER, Maria Elisa (org.). Revoluções de independências e nacionalismos nas Américas 1: região do Prata e Chile. Rio de Janeiro: Paz e Terra, 2007; e TERNAVASIO, Marcela. Gobernar la revolución. Poderes en disputa en el Rio de la Plata, 1810-1816. Buenos Aires: Siglo XXI, 2007. 
ligações comerciais com outros portos atlânticos da América, até os da embocadura do Rio da Prata. ${ }^{13}$

Mas a costumeira falta de atenção da historiografia voltada aos temas políticos luso-americanos em relação ao que se passava nas vizinhanças territoriais do Brasil levou a pelo menos um equívoco histórico, que seria reiterado por décadas sem que, aparentemente, dele ninguém tenha se dado conta. A origem, muito provavelmente, foi uma das informações do Correio Braziliense, contidas na edição de junho de 1817, e anteriormente referidas, segundo a qual - repitamos - seguira desde o Recife, a mando dos revolucionários de Pernambuco, "Felix José Tavares de Lima [sic] para Buenos Aires, a fim de tratar também com o Governo Insurgente do Paraguai”.

Quase nada se sabe dos dados biográficos deste ilustre senhor, que, poucos anos mais tarde, entre 1821 e 1822, representaria Pernambuco como deputado nas Cortes Gerais e Extraordinárias da Nação Portuguesa, e que já no Período Regencial brasileiro (1831-1840) presidiria, por poucos meses (entre setembro e dezembro de 1833), a mesma província. E absolutamente nada se escreveu acerca de sua suposta missão a Buenos Aires em 1817. Mesmo assim, desde a publicação de o Correio Braziliense, a idéia de que isso ocorreu tornou-se canônica. ${ }^{14}$ Talvez o primeiro a subscrever tal informação tenha sido o cônego Joaquim Caetano Fernandes Pinheiro, em artigo publicado na Revista do Instituto Histórico e Geográfico Brasileiro em 1861. Escrevendo em meio a polêmicas em torno do legado e da documentação atinente à revolução de 1817, as quais envolveram Francisco Adolfo de Varnhagen, Francisco Muniz Tavares, e a criação do Instituto Arqueológico e Geográfico Pernambucano (1862), Fernandes Pinheiro afirmava que,

Conhecendo-se baldo de meios para empenhar a luta com a monarquia, buscou o governo provisório a cooperação das nações que, por seus princípios liberais, pudessem simpatizar coma sua causa; e, para esse fim, enviou aos Estados Unidos da América Antonio Gonçalves da Cruz (Cabugá) e Felix José Tavares de Lima a Buenos Aires com instruções de entender-se com os sublevados do Paraguai. ${ }^{15}$

13 TEJERINA, Marcela. Luso-brasileños em el Buenos Aires virreinal. Trabajo, negócios e intereses em la Plaza naviera y comercial. Bahia Blanca: EDIUNS, 2004.

${ }^{14}$ Em aspecto foi inicialmente analisado em PIMENTA, João Paulo G. O Brasil e a América espanhola..., p. 220-221.

15 PINHEIRO, J. C. Fernandes. Luiz do Rego e a posteridade - Estudo histórico sobre a revolução pernambucana de 1817. Revista do Instituto Histórico e Geográfico Brasileiro, v. 24, p. 378, 1861. Uma pequena biografia sobre Fernandes Pinheiro pode ser encontrada em MELO, Carlos Augusto. As histórias literárias do Cônego Fernandes Pinheiro e o 
Referindo-se ao próprio Hipólito José da Costa - seguramente a principal fonte de seu artigo, e que na passagem acima é quase uma transliteração daquele do jornal - Fernandes Pinheiro acresce que

ocorreu-lhe também o pensamento de constituir seu agente em Londres a um benemérito brasileiro, cujas opiniões temos com respeito citado, que não só por convicção, como principalmente por gratidão declinou de semelhante encargo. ${ }^{16}$

Tempos depois, um ávido e perspicaz leitor de o Correio Braziliense, o influente Manoel de Oliveira Lima (1867-1828), anotaria em seu Dom João VI no Brasil (1908), que os revolucionários de 1817 não teriam tido tempo nem oportunidade de "firmar solidariedade" com "as colônias revoltadas da América espanhola", ao passo que, no seu contato efetivo com os Estados Unidos, "a repercussão foi nula". ${ }^{17}$ Anos mais tarde, contudo, por ocasião do primeiro centenário da Revolução Pernambucana de 1817, Lima mudaria de tom e, em boa medida, influenciado pelo que lera no Correio, tornar-se-ia menos cuidadoso com as palavras. Escreve, então, que Antonio Gonçalves da Cruz, o Cabugá, tivera sua "missão diplomática resolvida a 11 de março, ao mesmo tempo [em] que Hipólito José da Costa era encarregado da representação em Londres, a qual recusou, e Felix José Tavares de Lima era mandado a Buenos Aires para pôr-se de acordo com os revoltosos do Prata" ${ }^{18}$ Embora não cite aí sua fonte, parece evidente tratar-se da edição de junho de 1817 de o Correio Braziliense, ou tomara a informação daí constante, de segunda mão, no artigo de Pinheiro Fernandes.

A partir de então, a versão de "Felix José Tavares de Lima" como agente, no Rio da Prata, dos insurgentes de Pernambuco, tomou foro de verdade incontestável. Em fins da década de 1950, coube a outro historiador atuante em Pernambuco, Amaro Quintas, reiterá-la, em capítulo publicado na influente História geral da civilização brasileira,

cânone literário brasileiro. Terra roxa e outras terras - Revista de Estudos Literários, v. 9 , p. 62-63, 2007.

${ }^{16}$ PINHEIRO, J. C. Fernandes. Luiz do Rego e a posteridade..., p. 378. Em nota ao seu artigo, Pinheiro acresce que, segundo "pessoa fidedigna", "Hipólito José da Costa, redator do Correio Braziliense, devia infinitos obséquios a el-rei D. João VI, que lhe mandava dar uma pensão, com que vivendo folgadamente em país estrangeiro, grande serviço prestava a seu país pela liberdade com que advogava à sua causa". Idem, p. 456, nota 17. Embora esta seja informação curiosa e de interesse, lembramos que Fernandes Pinheiro não era historiador notável por conferir rigorosamente suas fontes.

${ }^{17}$ LIMA, Manuel de Oliveira. Dom João VI no Brasil (1808-1821). Rio de Janeiro: Tipografia do Jornal do Commercio de Rodrigues \& C., 1908, v. 2. p. 806.

18 TAVARES, Francisco Muniz. História da revolução de Pernambuco em 1817. (Revista e anotada por Oliveira Lima). Recife: Imprensa Industrial, 1917, p. 87. 
então dirigida por Sérgio Buarque de Holanda. Com base em uma fonte secundária - ou Pinheiro Fernandes ou Oliveira Lima - repetiria Quintas: "A Buenos Aires foi mandado Félix José Tavares de Lima para entrar em ligação com os rebeldes do Paraguai". ${ }^{19}$ A informação, agora abreviada, era ainda mais deturpada, pois o objetivo principal da suposta missão tornava-se, agora, o Paraguai. Na década de 1970, a informação ganharia as páginas de outra obra muito influente, desta vez seguramente tendo por fonte o artigo de Fernandes Pinheiro. A nova edição da História Geral do Brasil, de Varnhagen (a primeira é de 1854), manteria as lacônicas referências originais do autor a "algumas resoluções mais profícuas" da revolução de 1817, que ele tanto deplorara e quisera esquecer. ${ }^{20}$ Dentre elas, o fato de terem sido "mandados dois agentes, um aos Estados Unidos" e outro à Inglaterra, sem menção ao do Rio da Prata. ${ }^{21}$ Coube, então, a Rodolfo Garcia “informar", em nota complementar, que "para Buenos Aires, como agente dos revolucionários pernambucanos, foi enviado Felix José Tavares de Lima, com instruções especiais para tratar com os sublevados do Paraguai". 22

Na mesma década de 1970, o estudo de Carlos Guilherme Mota, Nordeste 1817, centrado na análise do que o autor chama de "vida mental" da sociedade de fins da era colonial, também apontou para a questão dos emissários do governo revolucionário, mas sem citar quaisquer fontes: a informação se consolidava como verdade de domínio público. "No plano exterior", escreve Mota, "foram enviados emissários aos Estados Unidos (Antonio Gonçalves da Cruz, o Cabugá, e Domingos Pires Ferreira, parente de Gervásio), a Buenos Aires (Félix Tavares de Lima) e à Inglaterra (com a intenção de articular Hipólito José da Costa, antigo conhecido de Domingos José Martins)". ${ }^{23} \mathrm{Na}$

${ }^{19}$ Cf.: QUINTAS, Amaro. A agitação republicana no Nordeste. In: HOLANDA, S. B. de. (dir.). História geral da civilização brasileira. São Paulo: Difusão Europeia do Livro, 1970, tomo 2, v. 1, p. 221.

${ }^{20}$ A má vontade de Varnhagen para com a revolução pernambucana é profícua: "Eis que uma revolução, proclamando um governo absolutamente independente da sujeição à corte do Rio de Janeiro, rebentou em Pernambuco em Março de 1817. É um assunto para o nosso ânimo tão pouco simpático que, se nos fora permitido passar sobre ele um véu, o deixaríamos fora do quadro que nos propusemos traçar...". VARNHAGEN, F. A. História geral do Brasil antes de sua separação e independência de Portugal. 9. ed. (Revisão e notas de Rodolfo Garcia). São Paulo: Melhoramento, 1978, tomo V, p. 149.

${ }^{21}$ Idem, p. 167-168.

${ }^{22}$ Idem, p. 183.

${ }^{23}$ MOTA, Carlos G. Nordeste 1817: estruturas e argumentos. São Paulo: Perspectiva, 1972, p. 56. No mesmo ano de 1972, o historiador aqui em questão repete a mesma formulação em outro ensaio: MOTA, Carlos G. O processo de independência no Nordeste. In: MOTA, Carlos G. (org.). 1822: dimensões. São Paulo: Perspectiva, 1972, p. 219. 
década seguinte, Glacyra Lazzari Leite foi além; não apenas afirmou que "para Buenos Aires, seguiu um emissário, Felix Tavares Lima", como também agregou dados que pareciam conferir caráter incontestável àquela informação. Elaborou uma ampla discussão baseada em cartas diplomáticas de Carlos Alvear - figura de destaque na política portenho da época, e que em 1817 vivia no Rio de Janeiro - sobre as relações entre Pernambuco e a região do Rio da Prata. Alvear relatava acontecimentos de 1817 a lideranças políticas de Buenos Aires, em missivas que foram interceptadas pelo encarregado dos negócios britânicos no Rio de Janeiro, Henry Chamberlain, o qual, ademais, as apresentou ao próprio príncipe regente D. João. Assim, Leite sugere que era grande o interesse dos "governantes da região do Prata" em torno do sucesso da Revolução Pernambucana, o que, aliás, pudemos confirmar amplamente em outros trabalhos. ${ }^{24}$ Finalmente, em seu importante estudo sobre os deputados do Brasil nas Cortes de Lisboa, publicado em 1999, Márcia Berbel mantém a escrita, ao referir que, dentre os deputados enviados por Pernambuco àquela assembléia, constava "Felix José Tavares Lira, que foi o emissário do governo revolucionário em Buenos Aires". ${ }^{25}$

\section{Tavares Lira: o que fez e o que não fez}

Seis meses depois de veicular a informação a respeito do suposto enviado de Pernambuco ao Rio da Prata, o Correio Braziliense publicou uma discreta nota retificadora:

\section{Resposta a Correspondentes.}

Recebemos a Carta datada de 27 de Dezembro, sobre Felix José Tavares de Lima, de quem se tinha dito no Corr. Braz. de Junho, p. 674, que fora mandado pelo Governo Provisório de Pernambuco, como seu Agente para Buenos Aires.

O nosso correspondente assevera que aquele sujeito é um respeitável proprietário de terras em Pernambuco, que se acha agora em Pernambuco e nunca dali saiu, que não foi empregado pelo Governo Revolucionário, nem nesta missão nem em outra alguma cousa.

\footnotetext{
${ }^{24}$ PIMENTA, João Paulo G. Estado e nação..., p. 156-160; PIMENTA, J. P. O Brasil e a América espanhola..., p. 217-238; LEITE, Glacyra. Pernambuco, 1817, p. 222.

${ }^{25}$ BERBEL, Márcia Regina. A nação como artefato..., p. 62. A historiadora repete essa informação em outra ocasião: BERBEL, M. R. Pátria e patriotas em Pernambuco (18171822): nação, identidade e vocabulário político. In: JANCSÓ, István. Brasil: formação..., p. 359. Aí, ela afirma ter como fonte de informação COSTA, F. A. Pereira da. Dicionário bibliográfico de pernambucanos célebres. Recife: Tipografia Universal, 1882. No entanto, não encontramos nesta obra quaisquer referências ao sujeito em questão.
} 
Temos grande prazer em corrigir um erro desta natureza, que pode ser tão prejudicial aos indivíduos. É impossível, porém, verificar a exatidão e todas as notícias que recebemos. ${ }^{26}$

Com receio de prejudicar um indivíduo, Hipólito da Costa acabaria por prejudicar a historiografia. Pois, se sua informação de junho de 1817 conheceria ampla difusão futura, à retificação de dezembro daquele ano não seria dada a mesma fortuna. E assim, gerações de historiadores acreditaram em um equívoco, pois, de fato, Félix Tavares não foi designado, nem viajou ao Rio da Prata, como agente da revolução. Mas por que a confusão pôde se estabelecer? Afinal, quem era e o que fazia Félix Tavares?

Um primeiro problema para sua identificação precisa concerne ao fato de que, nas duas vezes que a ele se reportou, Hipólito José da Costa se equivocou com a grafia de seu nome: ele não se chamava "Felix José Tavares de Lima", como aparece grafado nas edições de maio e dezembro de 1817 do Correio Braziliense, mas sim Felix José Tavares de Lira, como aparece em dezenas de outros documentos a seu respeito. ${ }^{27} \mathrm{Em}$ alguns documentos manuscritos que compulsamos, não há, ademais, o "de", mas uma forma direta: Tavares Lira.

Também não sabemos quando Felix José Tavares Lira nasceu ou morreu - o que soa estranho, considerando tratar-se de sujeito da elite proprietária pernambucana dos séculos XVIII e XIX que, como se sabe, foi deputado por sua província nas cortes de Lisboa e assumiu, mesmo que apenas por alguns meses, sua presidência em 1833. A primeira informação a seu respeito é que era filho único do capitão Felix José Tavares de Lira e de sua esposa Isabel Gonçalves de Freitas. Certamente nasceu no último quartel do século XVIII, no seio de família abastada na freguesia de Una, no sul da capitania de Pernambuco. Por volta de 1741, seu pai homônimo fora comandante "de uma das Companhias do Porto Calvo e Sirinhaém", povoações situadas naquela freguesia, onde ostentava o título colonial de senhor de engenho. ${ }^{28}$ Anos mais tarde, a 9 de dezembro de 1791, seu filho recebeu carta patente "para exercer o Posto de Capitão de uma das Companhias de Infantaria da Ordenança

${ }^{26}$ Correio Braziliense, dezembro de 1817, p. 678.

${ }^{27}$ Incorremos no equívoco relativo ao seu nome em PIMENTA, João Paulo G. O Brasil e a América espanhola..., p. 220-221.

${ }^{28}$ Certidão do escrivão do Cível e Crime de Olinda e Recife, José Caetano Rosa, atestando que o capitão José Tavares de Lira se encarregou de uma das Companhias do Porto Calvo e Sirinhaém, obedecendo a uma portaria do governador da capitania de Pernambuco, Henrique Luís Pereira Freire de Andrada. Cx. 57, doc. 4892, Recife, 05.08.1741. 
da Freguesia de Una", em decorrência de ter sido "proposto em primeiro lugar pelos oficiais da Câmara da Vila de Sirinhaém, com assistência do Capitão Mor da mesma". ${ }^{29}$ Tais honrarias mantinham-se de pai para filho, conferindo distinção à chamada "nobreza da terra". ${ }^{30}$

Dois anos mais tarde, Isabel Gonçalves de Freitas e "seu filho Felix José Tavares Lira" recorriam à rainha na condição de "senhores e possuidores de dois engenhos de fazer açúcar, a saber: Buenos Aires, na Comarca das Alagoas, e Brejo, na Comarca de Pernambuco". Denunciavam que outros senhores vizinhos "perturbam aos Suplicantes na usurpação de suas terras, movendo-lhes pleitos injustos, e outras inquietações, principalmente João Pimentel Perdigão e Antonio Ferrão Castelo Branco". Solicitavam, então, a "demarcação judicial" de suas terras "na forma da Lei do Reino e estilo que se deve observar nos Domínios de Vossa Majestade". ${ }^{31}$ Certamente o velho Tavares Lira já havia falecido, o que levava sua viúva e seu filho único - e homônimo - a mover a ação. No entanto, por volta de 1805, Felix José Tavares Lira (filho) demonstrava ser hábil nos negócios, uma vez que havia aumentado seu patrimônio. Nesse ano, possuía na capitania de Pernambuco não apenas dois, mas três engenhos. ${ }^{32}$

Ora, o nome de um dos engenhos da família parece elucidar uma das origens da informação equivocada veiculada pelo Correio Braziliense em junho de 1817. O Buenos Aires - que não era, claro, a cidade de Buenos Aires - era, ademais, engenho muito antigo. As primeiras referências a ele datam do século XVI. ${ }^{33}$ Por outro lado, Félix José

${ }^{29}$ Requerimento de Félix José Tavares Lira à D. Maria I, pedindo a confirmação da patente no posto de capitão de um das Companhias de Infantaria da Ordenança da freguesia de Una. AHU-PE, cx. 184, doc. 12792. 11.09.1793.

${ }^{30}$ Sobre o modo de vida, títulos e postos militares de senhores de engenho no Brasil colonial: SCHWARTZ, Stuart B. Segredos internos. Engenhos e escravos na sociedade colonial (15501835). Trad. Laura Teixeira Motta. S. Paulo/Brasília: Cia. das Letras/CNPq, 1988, cap. 10.

${ }^{31}$ Requerimento de Isabel Gonçalves de Freitas e seu filho Félix José Tavares Lira à D. Maria I, pedindo provisão para tombar, medir e demarcar as terras dos Engenhos Buenos Aires, na comarca das Alagoas, e Brejo na comarca de Pernambuco. AHU-PE, cx. 184, doc. 12795. S/1, 19.09.1793.

32 Aviso do secretário de estado da Marinha e Ultramar, visconde de Anadia, ao conselheiro do Conselho Ultramarino, Aires Pinto de Sousa, visconde da Lapa, ordenando que se defira ou consulte o requerimento do capitão da Primeira Companhia da Ordenança da capitania de Pernambuco, Félix José Tavares de Lira. AHU-PE, cx. 254, doc. 17005. Lisboa, 02.05.1805.

${ }^{33}$ A comarca de Alagoas, onde se localizava o engenho Buenos Aires, fora parte da capitania, e, depois, província de Pernambuco até 16 de setembro de 1817, quando foi emancipada por ato régio de Dom João. $C f$ : COSTA, Francisco Augusto Pereira da. Anais pernambucanos. 2. ed. Recife: FUNDARPE, 1983, v. 1, 2 e 7, respectivamente, p. 574, 184 e 541; GOMES, Geraldo. Engenho e arquitetura. Recife: FUNDAJ/Massangana, 2006. 
Tavares Lira possuía navio em sociedade com seu cunhado, Francisco Manoel da Silva Gusmão. Tinha, pois, negócios diversificados como era comum entre gente abastada na colônia -, uma vez que articulava a posição de senhor de engenho com a de senhorio de navio e comerciante, além de desempenhar funções políticas e burocráticas na Câmara do Recife, como se verá adiante. Seu navio, todavia, denominado Flor de Una - uma homenagem explícita à sua freguesia de nascimento - perfazia estranhas rotas entre a Europa e a América, provavelmente levando e trazendo, além de contrabando, informações oriundas de redes de sociabilidades que talvez passassem pela maçonaria.

A primeira referência ao Flor de Una que pudemos encontrar data de dezembro de 1801, quando o navio em questão, como muitos outros daqueles anos, recebera licença para voltar a Pernambuco desde Lisboa, contanto que partisse "armado em guerra", dado o hostil ambiente do Atlântico daqueles anos. ${ }^{34} \mathrm{Um}$ ano depois, o cônsul português em Cádiz, no sul da Espanha, Henrique Ribeiro Neves, pedia informações ao Visconde de Anadia, no sentido de saber se podia ou não conceder uma licença ao Flor de Una. Segundo o cônsul, este seguia viagem desde Buenos Aires - agora, sim, a cidade, e não o engenho - e insistia em partir de Cádiz diretamente ao Recife. O cônsul afirmava não saber se o navio poderia ou não "sair para os nossos portos da América sem primeiro ir a essa [Cidade de Lisboa]”. Anadia, por sua vez, foi enfático, ao assinalar que:

Se este Navio que se pretende navegar de Cádiz em direitura para Pernambuco fosse verdadeiramente em lastro, como se diz, não poderia haver grande inconveniente em se conceder essa Licença; mas o receio de haver contrabando, e o mau exemplo de semelhante concessão contraria ao princípio e a prática estabelecida, posto que alguma vez já possa ser alterado, de não admitir navegação alguma direta de Portos Estrangeiros para os do Brasil, ainda em Navios Portugueses, faz toda a dificuldade para a presente decisão, que V. Senhoria poderá muito melhor resolver com as suas superiores luzes.

Com isso, o problema seguiu de volta a Cádiz. ${ }^{35}$

${ }^{34}$ Ofício da Junta Governativa da capitania de Pernambuco ao secretário de estado da Marinha e Ultramar, visconde de Anadia, sobre a viagem para o porto de Pernambuco do navio Flor de Una, armado em guerra. AHU-PE, cx. Recife, 16.12.1801.

35 Ofício do Cônsul português em Cádiz, Henrique Ribeiro Neves, ao secretário de estado da Marinha e Ultramar, visconde de Anadia, sobre se dar ou não permissão ao navio Nossa Senhora da Piedade Flor de Una, de que é capitão Bernardo Pereira dos Santos, para seguir 
Em 27 de novembro de 1804, Felix José Tavares Lira vendeu a um morador de Lisboa, José Luís da Silva, metade da referida embarcação outrora pertencente ao seu cunhado, Francisco Manoel da Silva Gusmão. Tavares Lira fez o negócio pessoalmente, uma vez que se achava na corte portuguesa solicitando títulos, honras e cartas patentes para si e para Gusmão, bem como resolvendo negócios para este, o qual também era proprietário de três engenhos de açúcar em Pernambuco. Sua maior cartada foi dada naquele mesmo ano, quando solicitou ao príncipe regente mercê do hábito da Ordem de Cristo. Para justificar o mérito de tamanha honra, Tavares Lira sustentou que tinha "servido a S.A.R. com desempenho não só nos cargos públicos de Juiz Vereador" da vila de Santo Antônio do Recife, bem como que havia exercido, na mesma vila, cargo de "Almotacel por duas vezes". Ademais, aproveitando-se da situação de fragilidade do Império Português diante do contexto político e militar europeu, quis tirar proveito também dos "serviços que prestou com sustentar sua Companhia e fornecê-la de pólvora e balas no tempo em que os Franceses na guerra passada cruzavam aquela Costa". Como era típico por aqueles anos, também aduziu "os serviços de seu Pai", que fora igualmente capitão das tropas de Ordenanças de Pernambuco, como já vimos. ${ }^{36}$ Transitando entre a honra e o proveito, sabemos que Tavares Lira permaneceu em Lisboa entre 1801 e 1805, apresentando-se como "Capitão da Primeira Companhia das Ordenanças da vila de Sirinhaém", e ao seu cunhado como "capitão de Cavalaria Auxiliar de Olinda e senhor de três engenhos". Representava a si mesmo, ainda, como "nobre" da América: em seu processo objetivando o hábito da ordem de Cristo, afirmou, pelos santos evangelhos, "o ter vivido sempre a Lei de Nobreza não só em Pernambuco donde é natural, como em todo o tempo que tem estado em

viagem à capitania de Pernambuco com carga de couros e outros efeitos. AHU-PE, cx. 239, doc. 16083. Cádiz, 19.12.1802. Não era a primeira vez que o navio Flor de Una criava embaraços ao Estado português. Em 1799 foi lavrada no Juízo da Índia e Mina a “execução de sentença em que é autor Félix José Tavares de Lira e réus Domingos Magalhães Queirós e Mr du Meausseaux". Tal processo, ademais, "refere a galera "Flor de Una" proveniente de Pernambuco (Brasil)". ANTT, Feitos Findos, Juízo da Índia e Mina, maço 27, n. 13, cx. 27. É importante informar ao leitor que não consultamos esse processo, mas apenas verificamos sua existência nos catálogos referentes ao Arquivo Nacional da Torre do Tombo, em Lisboa.

${ }^{36}$ Aviso do secretário de estado da Marinha e Ultramar, visconde de Anadia, ao conselheiro do Conselho Ultramarino, Aires Pinto de Sousa, visconde da Lapa, ordenando que se defira ou consulte o requerimento do capitão da Primeira Companhia da Ordenança da capitania de Pernambuco, Félix José Tavares de Lira. AHU-PE, cx. 254, doc. 17005. Lisboa, 02.05.1805. 
Lisboa". ${ }^{37}$ Finalmente, em agosto de 1805, solicitou "passaporte para retornar à capitania de Pernambuco". ${ }^{38}$

Existem ainda alguns elementos esparsos que sugerem que Félix José Tavares Lira possuía vínculos com a maçonaria - e talvez fosse por isso que, por volta de 1802, o Flor do Una fosse de Cádiz ao Rio da Prata, incluindo Pernambuco. ${ }^{39}$ Ao mesmo tempo, sua presença em Lisboa em 1801, à época da conspiração dos Suassunas, bem como sua intimidade com um dos irmãos Cavalcanti envolvido naquele evento, podem nos levar a sugerir que ele tentava, sob o disfarce de nobre dos trópicos, estabelecer vínculos com agentes da maçonaria francesa e portuguesa. Com efeito, em seu processo para obter hábito da Ordem de Cristo, Lira valeu-se de depoimento de José Francisco de Paula Cavalcanti e Albuquerque, o qual também era proprietário de engenho localizado ao sul da capitania de Pernambuco onde, de acordo com outras fontes coligidas por historiadores, realizavamse reuniões maçônicas desde pelo menos 1801.40 José Francisco ainda "teria sido o agente da conjura" dos Suassunas (1801) na

37 Idem, ibidem.

${ }^{38}$ Requerimento do capitão da Primeira Companhia das Ordenanças da vila de Sirinhaém, Félix José Tavares de Lira, ao príncipe regente, D. João, pedindo prorrogação de um ano em sua licença para permanecer na Corte. AHU-PE, cx. 234, doc. 15767. Lisboa, 08.05.1802; Requerimento do capitão de Cavalaria Auxiliar de Olinda e senhor de três engenhos, Francisco Manoel da Silva Gusmão, por seu procurador Félix José Tavares de Lira, ao príncipe regente, D. João, pedindo o posto de tenentecoronel do mesmo Regimento. AHU-PE, cx. 256, doc. 17143. Lisboa, 06.08.1805; Requerimento do capitão de uma das Companhias da Ordenança de Sirinhaém, Félix José Tavares de Lira, ao príncipe regente, D. João, pedindo passaporte para retornar à capitania de Pernambuco. AHU-PE, cx. 256, doc. 17162. Lisboa, 20.08.1805.

${ }^{39}$ A história do surgimento de sociedades maçônicas costuma estar sempre envolta em muita confusão, em boa medida propiciadas pelas interpretações apologéticas de estudiosos maçons. No Rio da Prata, sabe-se de um incipiente movimento associativo desse tipo no ano de 1801, com o grupo dedicado à edição do primeiro periódico da região, o Telégrafo Mercanti, Rural, Político-económico e Historiográfico del Rio de la Plata, sendo reforçado entre 1806 e 1807 com as invasões inglesas. É possível que, nesses anos, já existisse aí alguma loja maçônica, mas disso não há prova cabal. GONZÁLEZ BERNALDO, Pilar. Civilidad y política en los orígenes de la Nación Argentina. Las sociabilidades en Buenos Aires, 1829-1862. Buenos Aires: FCE, 2001, p. 77-82.

40 MOREL, Marco \& SOUZA, Françoise Jean. O poder da maçonaria. A história de uma sociedade secreta no Brasil. Rio de Janeiro: Nova Fronteira, 2008, p. 69. A maçonaria deve ter chegado à América portuguesa entre fins do século XVIII e os primeiros anos do XIX. Em 1801, provavelmente já havia uma loja no Rio de Janeiro e, no ano seguinte, outra na Bahia. Também: BARATA, Alexandre M. Maçonaria, sociabilidade ilustrada e independência do Brasil (1790-1822). São Paulo/Juiz de Fora: Annablume/Editora UFJF/ FAPESP, 2006. 
Europa,${ }^{41}$ onde estivera "a fim de obter o apoio de Bonaparte, graças às conexões maçônicas que dispunha em Paris". Com sua estada na Europa nos primeiros anos do século XIX, "será nomeado representante do Grande Oriente de França junto ao Grande Oriente lusitano, tornandose um dos negociadores do convênio de cooperação entre ambos". ${ }^{42} \mathrm{De}$ fato, há informações abundantes sobre a presença de José Francisco em Lisboa por esses anos, o que favoreceu Tavares Lira quando este precisou de gente que depusesse a seu favor no processo que moveu a partir de 1804, para obtenção de um hábito da Ordem de Cristo. ${ }^{43}$ Nessa circunstância, José Francisco de Paula Cavalcanti e Albuquerque se disse "Cavaleiro Professo na Ordem de Cristo, que vive de suas Fazendas"; quando perguntado sobre Félix José Tavares Lira, respondeu "que o conhece perfeitamente, em razão dele, Testemunha, ser natural de Pernambuco". ${ }^{44}$

Assim, os vínculos estabelecidos entre os Cavalcanti e Félix José Tavares Lira parecem ter ido além da obtenção de posições na ordem estamental vigente: eles também estavam envolvidos em tramas urdidas em meio a espaços de sociabilidade incipientes, e ainda reservados. Como diz um especialista no tema, "Bahia e Pernambuco eram também centros maçônicos importantes no início do século XIX”. Segundo ele pôde apurar em pesquisas em processos do Santo Ofício, a maçonaria crescia "tanto no 'mato' quanto no Recife" e, com efeito, reporta-se ao caso do capitão José Carlos Paes Barreto, que era proprietário do engenho Saltinho, localizado na mesma Freguesia do Uma, onde nascera Tavares Lira: em 1808, ele denunciou o padre José Felício por convidá-lo

${ }^{41}$ MARTINS, Padre Joaquim Dias. Os mártires pernambucanos vitimas da liberdade nas duas revoluções ensaiadas em 1710 e 1817. Recife: Tipografia de F. C. Lemos e Silva, 1853, p. 12; RODRIGUES, José Honório. A inconfidência de 1801. In: Documentos Históricos (v. CX). Rio de Janeiro: Biblioteca Nacional, 1955, p. 12-13. (Doravante D.H. e volume correspondente)

${ }^{42}$ MELLO, Evaldo Cabral de. A outra independência. O federalismo pernambucano de 1817 a 1824. Rio de Janeiro: Editora 34, 2004, p. 25.

${ }^{43}$ Requerimento do capitão do Corpo de Artilheiros do Recife, José Francisco de Paula Cavalcanti e Albuquerque, por seu procurador José Maria de Albuquerque e Melo, ao príncipe regente D. João, pedindo um ano de licença para ir à Corte. AHU-PE, cx. 213, doc. 14448. S/1, 10.01.1800; escrevendo em 1823, o Padre Joaquim Dias Martins acresce que "José Francisco de Paula, então em Lisboa, figurava na conjuração de agente acreditado junto ao protetor [Napoleão]; e escapou de ser preso fugindo para a Inglaterra". MARTINS, Padre Joaquim Dias. Os mártires..., p. 12.

${ }^{44}$ Aviso do secretário de estado da Marinha e Ultramar, visconde de Anadia, ao conselheiro do Conselho Ultramarino, Aires Pinto de Sousa, visconde da Lapa, ordenando que se defira ou consulte o requerimento do capitão da Primeira Companhia da Ordenança da capitania de Pernambuco, Félix José Tavares de Lira. AHU-PE, cx. 254, doc. 17005. Lisboa, 02.05.1805. 
para ser "Pedreiro Livre", uma vez que tal ofício "não era contrário a Santa Fé Católica". Mais ainda: "José Felício também teria lhe dito que fosse a casa de Félix José Tavares de Lira, que este lhe 'diria como se havia reger, e que se lhe havia dar um livro para seu Regimento"”. Recomendava-lhe, ademais, que convidasse amigos para ser iniciado na maçonaria, "porém que fosse dos mais principais e não Publicanos", isto é, que não fosse burocrata da Coroa. ${ }^{45}$

Era paradoxal que gente da elite açucareira da capitania de Pernambuco ocupasse postos importantes, solicitasse hábito de ordens militares ao príncipe e, ao mesmo tempo, fosse acusada de sedição. José Francisco de Paula Cavalcanti e Albuquerque, por exemplo, encarnava tudo isso: era possuidor de hábito da Ordem de Cristo, foi governador do Rio Grande do Norte, de São Miguel, nos Açores, e de Moçambique, e se viu acusado de crime de lesa-majestade justamente quando se achava em Lisboa, em 1801. Os vínculos com a maçonaria, curiosamente, como propõe Evaldo Cabral de Mello, não apenas levavam ao confronto com a ordem do Antigo Regime, como também pareciam ajudar na obtenção de postos, títulos e posições dentro desta mesma ordem política. ${ }^{46}$ Ao mesmo tempo, não poderia haver melhor disfarce para simpatizantes dos republicanismos que surgiam por aqueles anos no mundo atlântico que ingressar em ordens tradicionais. É provável que Félix José Tavares Lira, apesar de sua descrição costumeira, mantida, aliás, ao longo dos anos, estivesse envolvido até os ossos em tramas políticas daqueles anos, ainda obscuras para a historiografia. Isso não poderia explicar o empenho de Hipólito da Costa em retificar uma informação incorreta que "denegria" um indivíduo, como ele próprio, maçom? Não haveria aí a demonstração de uma solidariedade corporativa típica dessas associações coletivas?

Para além de informações esparsas sobre as atividades reservadas - quiçá clandestinas - de Félix José Tavares Lira, existem outras, atinentes à sua trajetória política pública. Seguramente, ele tinha contatos próximos com líderes da revolução de 1817 , caso dos

${ }^{45}$ BARATA, Alexandre M. Francisco Álvaro da Silva Freire: negociante portuense e maçom. Texto apresentado no XI Encontro Regional de História. Rio de Janeiro, UERJ, 2004. A noção de 'publicano' refere-se, segundo Bluteau, a "Cobrador, ou assentista das rendas e dinheiros públicos, como tributos ou impostos sobre o sal, vinho, carnes etc." $C f$.: Vocabulário português e latino ... oferecido a El Rey de Portugal Dom João V, pelo Padre D. Raphael Bluteau. (Vol. 6). Coimbra: Colégio das Artes da Companhia de Jesus, 1712, p. 816-817.

${ }^{46}$ MELLO, Evaldo Cabral de. A outra independência..., p. 25 e passim. 
irmãos Cavalcanti. ${ }^{47}$ No entanto, é fabuloso como Tavares Lira soube dissimular seu envolvimento nestes acontecimentos, provavelmente permanecendo a maior parte do tempo em seu engenho Buenos Aires; e que a publicização de seu suposto envolvimento tenha sido desmentido por uma fonte que, infelizmente, o Correio Braziliense não nos indica qual foi. Assim, pois, não se deve estranhar que, nos índices onomásticos dos dez volumes da coleção Documentos Históricos, editados pela Biblioteca Nacional, nos quais se acham a larga maioria dos documentos diretamente relacionados àquele movimento que chegaram até nós, não se encontre uma só referência ao sujeito aqui em questão; ou que o padre Dias Martins, em seus apontamentos de 1823, não lhe dedique pequena biografia, tampouco a ele se refira como um "mártir pernambucano". Também Pereira da Costa ignorou-o por completo em seu Dicionário biográfico de pernambucanos célebres, de 1882, não lhe dedicando uma linha sequer. ${ }^{48}$

Na verdade, a atuação política aberta de Tavares Lira foi, em geral, de uma nulidade formidável. Sua aparição um pouco mais ostensiva na cena pública se deu no turbulento processo de consolidação dos princípios do constitucionalismo em Pernambuco. Houve ali uma tensão deveras particular. Diferentemente do que ocorrera na Bahia ou no Pará, onde juntas de governo foram criadas concomitantemente à escolha de deputados para as Cortes Gerais e Extraordinárias da Nação Portuguesa, em Pernambuco os dois processos eleitorais ocorreram divorciados um do outro. As eleições para as Cortes, sob a supervisão direta do governador Luís do Rego Barreto (1817-1821), tiveram início a $1^{\circ}$ de junho de 1821, quando se escolheu um corpo de eleitores; este, por sua vez, elegeu os deputados em 7 de junho de $1821 .{ }^{49}$ Foram eleitos, pela

${ }^{47}$ LEITE, G. L. Pernambuco..., p. 236.

${ }^{48}$ D.H. (v. CI-CX). Rio de Janeiro: Biblioteca Nacional, 1953-1955; MARTINS, Padre Joaquim Dias. Os mártires...; COSTA, F.A. Pereira da. Dicionário bibliográfico de pernambucanos célebres. Recife: Tipografia Universal, 1882.

${ }^{49}$ Carta do governador da província de Pernambuco, Luís do Rego Barreto, ao rei D. João VI, sobre a eleição dos deputados das comarcas de Recife e Olinda e dos preparativos para partirem à Corte. AHU-PE, cx. 282, doc. 19243. Recife, 16.06.1821; COSTA, F.A.P. da. Anais..., (v. 8), p. 141. A maior parte dos trabalhos sobre constitucionalismo dedica-se mais à formação da Junta de Governo que ao processo de eleição dos deputados ao Congresso lisbonense. Exceção é o estudo de Berbel, já citado, que, no entanto, se equivoca quanto à data da eleição, bem como não indica sua fonte para tal informação (BERBEL, M. R. A nação..., p. 60-61). Com efeito, procedeu-se às eleições a 7 de junho, e não a 26 de março. Esta última data, aliás, teve outro significado: representou o momento no qual, em Pernambuco, se soube do juramento de D. João VI às bases da Constituição espanhola, realizado um mês antes. $C f$ : Carta do governador da província de Pernambuco, Luís do Rego Barreto, ao rei D. João VI, sobre a inquietação causada pelo juramento do rei 
comarca de Olinda e Recife, o vigário Inácio Pinto de Almeida e Castro, Manuel Zeferino dos Santos, Pedro de Araújo Lima, João Ferreira da Silva, Domingos Malaquias de Aguiar Pires Ferreira, Padre Francisco Muniz Tavares e Félix José Tavares Lira, exatamente nesta ordem de votação. A 27 de agosto, os deputados por Pernambuco chegaram a Portugal - tratava-se de a primeira bancada provincial a desembarcar em Lisboa - e, dois dias depois, já estavam em plenário. ${ }^{50}$

O nome de Tavares Lira aparece nos Diários das Cortes a partir de 29 de agosto de 1821, mas sempre votando, ou para se assinalar sua ausência. Nenhuma vez a entrada de seu nome refere-se às suas falas, que, ao que parece, jamais ocorreram. Tavares Lira entrara mudo nas Cortes e saíra calado. Após várias faltas às seções entre setembro e novembro de 1821, solicitou licença de oito dias "para tratar da sua saúde" a 14 de março de 1822, a qual foi deferida. Após comparecer apenas a duas seções em maio, finalmente reapareceu como signatário da Constituição a $1^{\circ}$ de outubro de $1822 .{ }^{51}$ Passado os rigores do inverno, Tavares Lira solicitou passaporte para regressar a Pernambuco a 15 de março de 1823, "em companhia de um filho menor de 10 anos e dois Criados pretos". Servindo-se de "criados pretos" continuava ele, pois, vivendo "na Lei da Nobreza" em Lisboa, como dissera quase vinte anos antes. ${ }^{52}$ Contudo, tão logo desembarcou no Brasil, foi tomado pelas coisas da política, numa antiga e vasta ex-colônia que se declarara independente de sua metrópole poucos meses antes. Até o fim do ano de 1823, com a extinção das juntas de governo e a instituição do presidente de província pela própria Assembléia Constituinte do Rio de Janeiro, Pernambuco achava-se em estado desesperador. A reunião do Grande Conselho, a 13 de dezembro de 1823 - uma clara reprodução lusa do cabildo abierto hispânico, como bem notou Oliveira Lima ${ }^{53}$ - produziu uma ata aterradora:

à constituição e a convocação das Cortes em Portugal, as medidas tomadas para reprimir tais atos e para fazer com brevidade as eleições dos deputados. AHU-PE, cx. 282, doc. 19220. Recife, 02.04.1821. Ver também LIMA, Manoel de Oliveira. O movimento da independência (1821-1822). Rio de Janeiro: Topbooks, 1997, p. 127.

${ }^{50}$ COSTA, F. A. P. da. Anais..., (v. 8), p. 141; BERBEL, M. R. A nação..., p. 84.

${ }^{51}$ Diário das Cortes Gerais e Extraordinárias da Nação Portuguesa. Lisboa: Impressão Nacional, 1821-1822.

52 Atestado do intendente Geral da Polícia, Manoel Marinho Falcão de Castro, declarando que o ex-deputado da província de Pernambuco, Félix José Tavares Lira, possui os requisitos necessários para requerer passaporte para fazer viagem à dita província com dois criados pretos. AHU-PE, cx. 287, doc. 19750. Lisboa, 15 de março de 1823.

${ }^{53}$ LIMA, Manoel de Oliveira. O movimento da independência..., p. 127. 
... achando-se a Província bandeada e ameaçando uma Guerra Civil, havendo já Corpo reunido em Goiana, anunciando-se que não cessaria, sem que se mudasse o Governo, e sendo apresentadas a este Governo diversas peças comprovativas do fato, era um dever sagrado do Governo fazer cessar as calamidades públicas, poupando assim o Sangue Patriótico; e que não podendo conseguir-se este bem sem que sufocasse a Causa, ele e seus companheiros [...] rogavam a todos os Congregados, que em nome do bem da humanidade e da Província, e mesmo em nome do Grande Império Brasileiro, que os dispensassem de um Governo em [que] tinham perdido toda a força moral, e cuja continuação só podia produzir males incalculáveis e que sendo a salvação da Província a primeira Lei, eles desde já haviam por instantemente que se remediasse o mal criando-se um Governo precário [...] ${ }^{54}$

Foi nessa circunstância que Manoel de Carvalho Paes de Andrade - que poucos meses depois seria presidente e autor dos principais manifestos da chamada "Confederação do Equador" - foi eleito pela primeira vez para presidir a província de Pernambuco. Para a junta de governo, reunida sob bases tão precárias conforme já analisamos em outra oportunidade, ${ }^{55}$ foi escolhido como conselheiro Félix José Tavares Lira. Recebeu, então, 51 votos por parte dos membros do Grande Conselho. ${ }^{56}$ A junta provisória foi empossada a 15 de dezembro de $1823^{57}$ e, poucos dias depois, a 8 de janeiro de 1824, uma nova junta seria eleita, agora em caráter definitivo. Desta fariam parte, mais uma vez, Manoel de Carvalho Paes de Andrade, como presidente, e José de Natividade Saldanha, como secretário. Contudo, dos seis membros escolhidos na primeira eleição, três não se dispuseram a se candidatar outra vez, ou não foram reeleitos. Dentre eles estava Tavares Lira. Não parece, todavia, que sua ausência da junta definitiva fosse mera coincidência: ela se coadunava perfeitamente com um perfil construído ao longo de uma imperscrutável trajetória política. Ademais, aquele era um momento político delicado. Pernambuco preparava-se para viver um confronto anunciado desde o ano anterior, uma vez que partidários e críticos do projeto do Rio de Janeiro digladiavam-se no âmbito provincial. Por outro lado, era claro

${ }^{54}$ Atas do Conselho do Governo de Pernambuco (v. 1). Recife: ALEPE/APEJE, 1997, p. 214-215.

55 SILVA, Luiz Geraldo. O avesso da Independência: Pernambuco (1817-1824). In: MALERBA, Jurandir. (org.). A Independência brasileira. Novas dimensões. Rio de Janeiro: Editora FGV, 2006, p. 343-384.

56 Atas do Conselho..., p. 215.

${ }^{57}$ COSTA, F.A.P. da. Anais..., (v. 8), p. 476. 
o quadro de confrontação entre a junta eleita em janeiro de 1824 e o Império do Brasil. O resultado, como sabemos, foi a deflagração, em julho daquele ano, da Confederação do Equador - uma guerra civil provincial urdida com bloqueio naval e ataques por terra perpetrados pelo governo de D. Pedro I. ${ }^{58}$

Tavares Lira reapareceria nos anais da vida política pernambucana a 13 de março de 1830, quando assumiu vaga no Conselho do Governo da Província de Pernambuco, do qual era até então membro suplente. Naquela circunstância "tomou assento o Senhor Félix José Tavares de Lira, chamado pela ausência do Senhor Pires Ferreira". ${ }^{59}$ Substituíra, pois, Gervásio Pires Ferreira, que havia embarcado para o Rio de Janeiro dois dias antes como deputado à Assembléia Geral. Tavares Lira esteve presente ao Conselho desde então até 11 de dezembro de 1833. Ao longo desses anos ocupou o posto máximo de presidente do Conselho, à época em que também exercia a vice-presidência da província. Nessa condição, presidiu as sessões do Conselho de 4 de setembro a 25 de novembro de 1833. Em seu breve governo, o Conselho ficou por um mês - o de outubro - sem uma reunião sequer. ${ }^{60}$

O "caso" de Félix Tavares Lira sugere o quão pouco sabemos, até o momento, acerca das relações entre setores mais radicais de uma sociedade pernambucana em franca politização nas primeiras décadas do século XIX, com outros setores de outros espaços, como, notadamente, o Rio da Prata. Nossa hipótese é muito simples. Lutas políticas dessa região, bem como padrões institucionais, sobretudo das juntas de governo e suas respectivas formas políticas - mormente as que, de muitas e variadas maneiras, poderíamos chamar de "republicanas" e/ou "federalistas" além, claro, de declarações de independência como a das Províncias do Prata de 1816, influenciaram de modo decisivo concepções e ações políticas da época e do contexto específico de Tavares Lira. Por meio de relações comerciais, sociabilidades nascentes permeadas de conteúdos tradicionais, e ensaios políticos, por vezes francamente sediciosos, constitui-se um contexto amplo, geral e múltiplo, onde determinados componentes políticos - como o constitucionalismo moderno, primeiro dos Estados Unidos e França, logo os de Cádiz, Madri e Lisboa, e a concepção acerca das possibilidades de viabilização de novas ordens políticas, autônomas e soberanas - acabavam por interligar os espaços

\footnotetext{
${ }_{58}$ SILVA, Luiz Geraldo. Um projeto para a nação..., p. 199-216.

${ }^{59}$ Atas do Conselho..., v. 2, p. 89-90.

${ }^{60}$ Atas do Conselho..., v. 2, p. 222-273.
} 
lusos e hispânicos, europeus e americanos, bem como as modalidades de ligação destes com outros. Surge daí uma dinâmica de modelos políticos que ainda cabe conhecer melhor.

\section{Modelos políticos}

Por seu envolvimento na revolução de 1817, o padre Pedro de Souza Tenório - bem como outras oito pessoas residentes nas províncias de Pernambuco e Paraíba - foi condenado à morte e executado a 10 de julho de $1817 .{ }^{61}$ Antes disso, porém, revelou, em depoimento prestado a 7 de julho daquele mesmo ano, que fora "convidado, ou escolhido [...] por via de uma carta que Domingos José Martins lhe dirigiu para ir em missão a Buenos Aires, o que ele não aceitara". ${ }^{62}$ Ao contrário do que sucedeu ao enviado aos Estados Unidos da América, Antonio Gonçalves da Cruz, Tenório nunca saiu da província de Pernambuco e, antes, foi alçado à condição de secretário geral do governo revolucionário. Não obstante, seu depoimento informa o interesse efetivo revelado pelos revolucionários em torno dos acontecimentos do Rio da Prata, e quiçá de toda a convulsionada América espanhola daqueles anos. Ao mesmo tempo, revela como os revolucionários das províncias do Norte contaram com a possibilidade de receber apoio dos potentados rio-platenses para a causa que sustentavam. Que alguém poderia seguir para o Rio da Prata com essa finalidade, parece fora de dúvida; se o "homem errado", Félix José Tavares Lira, chegou a receber proposta como a que foi dirigida ao padre Tenório, não sabemos, embora a confusão entre duas as Buenos Aires - cidade hispânica e propriedade rural pernambucana - pareça indicar uma negativa.

Isto, porém, não quer dizer que houvesse efetivo perigo - do ponto de vista realista - de ação conjunta entre áreas tão remotas dos impérios português e espanhol. Ataques unilaterais por parte de republicanos da região do Rio da Prata constituíam objeto de temor por parte das autoridades do Reino Unido português, bem como das de suas províncias. Nessa matéria, parecia haver tendências conflitantes. Por um lado, a presença militar portuguesa em Montevidéu, concretizada em 1811 e, novamente, entre 1816 e 1817, demandava uma difícil política de equilíbrio de interesses entre autoridades realistas espanholas

${ }^{61}$ TAVARES, Francisco Muniz. História da revolução..., p. CCLXIII-CCLXIV; COSTA, F.A.P. da. Anais..., v. 7, p. 508.

${ }^{62}$ D.H., v. CII, p. 69-70. 
peninsulares, lideranças orientais e dirigentes portenhos, permeada pelos próprios interesses da Corte do Rio de Janeiro. ${ }^{63} \mathrm{~A}$ ascensão de José Gervasio Artigas, em evidência até 1820, tornava a situação ainda mais complicada e reverberava seus ecos também em Pernambuco. Em carta de 2 de setembro de 1818, o então governador e capitão general de Pernambuco, Luís do Rego Barreto, escreve ao governador do Rio Grande do Norte, José Inácio Borges, informando que:

Em consequência da nossa Guerra com o Partidário L'Artigas tem este dado passaportes em seu nome a quem quer armar contra os nossos Navios e tem-se inundado a Costa e os Mares de Corsários que como Ladrões do Mar atacam todas as Nações com a preferência Portugueses e Espanhóis e são compostas suas Equipagens de Marinheiros de todas as Nações sendo quase sempre a maior parte de Americanos; alguns dos nossos Navios têm sido roubados tendo os Corsários Bandeiras Inglesa e na Bahia tem feito insultos à vista da Cidade. ${ }^{64}$

Em outra missiva destinada ao governador da Paraíba, Barreto dava conta de ali ter fundeado um navio corsário vinculado ao governo de Buenos Aires, o qual, embora mantivesse presos dois marinheiros espanhóis, deveria ser tratado com cuidado e vigília, mas a distância. Afinal, era "do maior interesse para a causa das nossas Armas na margem esquerda do Rio da Prata conservar a boa inteligência e neutralidade que tem até agora subsistido entre os Generais e comandantes Portugueses e aquele governo". ${ }^{65}$

Por outro lado, havia entre grupos locais interesse recíproco nos destinos de ambas as comunidades políticas. Oliveira Lima nota que, quando esteve fundeado no porto de Pernambuco o navio La Perle,

${ }^{63}$ PIMENTA, João Paulo G. O Brasil e a América espanhola ..., p. 133, 197-198.

${ }^{64}$ Carta do governador da capitania de Pernambuco, Luís do Rego Barreto, a José Inácio Borges, Governador do Rio Grande do Norte, sobre a proposta de Milícias da dita Cidade, e os Corsários. Recife, 9 de setembro de 1818. Arquivo Público Estadual de Pernambuco. Série Ofícios do Governo, volume 17 (1818-1819), fls. 40v.-41. Sobre as práticas de corsários à época da independência da América espanhola, e suas vinculações com os governos rebeldes, ver o ensaio de GRAFENSTEIN, Johanna Von. Corso y piratería en el Golfo-Caribe durante las guerras de independencia hispanoamericanas. In: AUGERON, M. \& TRANCHANT, Mathias (Orgs.). La violence et la mer dans l'espace atlantique (XII ${ }^{\mathrm{e}}-\mathrm{XIX}{ }^{\mathrm{e}}$ siècle). Rennes: Presses UNIversitaires de Rennes, 2004, p. 269-282.

${ }^{65}$ Carta do governador da capitania de Pernambuco, Luís do Rego Barreto, ao governador da Paraíba, Thomaz de Souza Mafra, sobre circunstâncias políticas com o governo de Buenos Aires e a respeito de presos dos corsários espanhóis. Arquivo Público Estadual de Pernambuco. Série Ofícios do Governo, v. 17 (1818-1819). Recife, 17 de setembro de 1818, fls. 48,48 v, 49. 
em fevereiro de 1816, seu capitão Hareng escreveu "que a província não tardaria em participar no movimento revolucionário que sacudia a América espanhola", ${ }^{66}$ tamanha a atenção com a qual se acompanhavam os acontecimentos atinentes à crise do império vizinho:

Seguia-se com particular empenho os progressos dos insurgentes espanhóis, sabendo o próprio governo que existiam com eles inteligências pela via marítima. Para alterar-lhes o efeito, foi que o capitão general [Caetano Pinto de Miranda Montenegro (18041817)] entendeu fazer proclamações e passar revistas, recordando aos habitantes e às tropas a confiança e fidelidade para com o soberano, e prometendo pronta distribuição de víveres pois era sobretudo da carência de alimentação que os perturbadores tiravam partido para açular os ânimos. ${ }^{67}$

Com efeito, jornais portenhos, livros, notícias e boatos chegavam com relativa facilidade ao porto do Recife ao longo das décadas de 1810 e 1820. Por outro lado, notícias das rebeladas províncias do Norte da América portuguesa em 1817, conforme já apontamos, chegavam constantemente ao Rio da Prata. O Censor, editado em Buenos Aires, informava, em sua edição de $1^{\circ}$ de maio de 1817 , que a Revolução Pernambucana resultara de uma "comoção popular", a qual depusera o governador e dera bases para o surgimento de um governo de cinco pessoas, ao qual prestou sua obediência toda a guarnição. Têm-se tomado as medidas mais ativas para sufocar a revolução que toma $o$ caráter de uma verdadeira independência do rei e da metrópole. Por sua vez, a Gazeta de Buenos Ayres lamentou, em sua edição de 2 de agosto de 1817, o fim do movimento das "Províncias do Norte" da América portuguesa, mas evidenciou, ao mesmo tempo, o errado cálculo político de seus mentores. ${ }^{68}$

Finalmente, não se pode deixar de se perceber como fenômenos articulados a noções de federalismo e, mais timidamente, de republicanismo, bem como à adoção de instituições como juntas de governo e cortes constituintes, assaltaram o Reino Unido português entre 1817 e 1821, como decorrência direta de experiências pretéritas do mundo hispânico. Um ponto de partida importante para alinhavar esta formulação parte, necessariamente, do fato de que o motivo que fizera a Corte lusa vir para o Brasil em fins de 1807 era precisamente o

\footnotetext{
${ }^{66}$ LIMA, Manuel de Oliveira. Dom João VI no Brasil..., p. 813.

${ }^{67}$ Idem, ibidem.

${ }^{68}$ PIMENTA, J. P. G. Estado e nação..., p. 159-160.
} 
mesmo que precipitara o colapso da monarquia espanhola em $1808 .{ }^{69}$ Nesta, logo ocorreria a ativação de um princípio político tradicional que, até então, não tivera pretexto para ser mobilizado, pois, com o cativeiro francês da família real espanhola - que a portuguesa soubera evitar - o rei considerado legítimo pela maioria dos súditos hispânicos achava-se vivo, porém impedido de governar. Desse modo, na mentalidade pactista dominante, a soberania da nação retornava aos povos e as suas formas de representação típicas de Antigo Regime - a cidade, a câmara e, mais modernamente, a junta de governo. ${ }^{70} \mathrm{Em} 1808$, essa concepção, enraizada na tradição política e jurídica espanhola, se materializa simultaneamente na Europa e na América. Em ambos os contextos, falou-se em fidelidade ao monarca ausente, mas, ao mesmo tempo, reconheceu-se que, na falta deste, ou diante da vacatio regis, o poder voltava a residir nos povos. ${ }^{71} \mathrm{~A}$ formação de juntas, e a tentativa de coordenação entre elas, desembocaria, pouco depois, na formação de Cortes constituintes que, encarregadas de legislar sobre o Império Espanhol e para ele elaborar uma Constituição, acabariam por convocar representantes de toda a parte, europeus, americanos e asiáticos - parcialmente reunidos na Espanha - em um movimento que se revelaria modelar, ${ }^{72}$ principalmente para o mundo luso, que pouco depois formularia, preservando a forma monárquica de governo, suas próprias juntas de governo e cortes constituintes, ambas a partir de 1820 .

Desde 1814, quando da restauração de Fernando VII ao trono, porém, o acirramento das lutas intestinas no mundo hispânico criariam ambientes mais favoráveis a uma melhor definição de posturas e projetos, dentre os quais os republicanos tendiam, progressivamente, a

${ }^{69}$ ESDAILE, Charles. Las guerras de Napoleón. Una historia internacional, 1803-1815. Barcelona: Critica, 2009; ALEXANDRE, Valentim. Os sentidos do império. Questão nacional e questão colonial na crise do antigo regime português. Porto: Afrontamento, 1993, p. 125-123.

${ }^{70}$ GUERRA, François-Xavier. Modernidad e independencias. Ensayos sobre las revoluciones hispánicas. Madrid: Editorial Mapfre, 1992, p. 118-129.

${ }^{71}$ HALPERÍN DONGHI, Tulio. Tradición política española e ideologia revolucionaria de Mayo. Buenos Aires: Eudeba, 1961; CARAVAGLIA, Juan Carlos. Os primórdios do processo de independência hispano-americano. In: JANCSÓ, István (Org.). Independência: história e historiografia. São Paulo: Hucitec/FAPESP, 2005, p. 209-210.

${ }^{72}$ MÚNERA, Alfonso. El fracaso de la nación. Región, clase y raza en el Caribe colombiano (1717-1821). Bogotá: Editorial Planeta Colombiana, 2008, cap. VI; LASSO, Marixa. Myths of harmony. Race and republicanism during the Age of Revolution, Colombia, 1795-1831. Pittsburgh: University Pittsburgh Press, 2007, caps. 1, 2 e 4; LASSO, Marixa. Race War and Nation in Caribbean Gran Colombia, Cartagena, 1810-1832. The American Historical Review. v. 112, n.. 2, p. 336-361, April 2006.. 
se contrapor aos monarquistas, e modalidades de federalismo a interagir com vários deles. ${ }^{73} \mathrm{Nada}$, porém, que permitisse traçar distinções totalmente claras entre posições tão instáveis, dinâmicas e contraditórias. O que se passaria desde então na América espanhola contribuiria para moldar as coisas em Pernambuco, antes mesmo do advento das juntas e do constitucionalismo no Reino Unido português. No mesmo ano da revolução na província, portugueses de ambos os hemisférios - pois ainda em 1817 eclodia em Portugal a conspiração liderada por Gomes Freire de Andrade - articulavam, aos poucos, noções de federalismo e, mais timidamente, de republicanismo. Doravante, não haveria outro receituário para se seguir tão de perto quanto aquele que estava ao lado, no mesmo continente, ou no reino peninsular vizinho.

Em primeiro lugar, note-se que em 1817 as noções de federalismo, ou de liga, dominavam o cenário das discussões travadas nas províncias do Norte da América portuguesa, o que se remetia ao difícil arranjo político em curso, principalmente, no Rio da Prata. ${ }^{74}$ Um sujeito que vivenciou as experiências políticas das décadas de 1810 e 1820 em Pernambuco, o mais tarde deputado provincial e do império Antonio Joaquim de Melo, percebeu nitidamente que os projetos políticos emergentes no sul do continente constituíram a base de ações e pensamentos dos revolucionários de Pernambuco e adjacências em 1817. Também notou que a idéia de federação, configurada à maneira do Rio da Prata, teve impacto profundo sobre os eventos daqueles anos. Na biografia dedicada a Gervásio Pires Ferreira, observava que os

\footnotetext{
${ }^{73}$ Há distintas perspectivas de análise em torno dos aspectos decorrentes das cortes de Cádiz para a América. Para a perspectiva de conflito entre Europa e América: GUERRA, François-Xavier. Modernidad e independencias..., p. 135; RODRÍGUEZ O., Jaime E. El nacimiento de Hispanoamérica. Vicente Rocafuerte y el hispanoamericanismo, 18081832. Quito: Corporación Editora Nacional/Universidad Andina Simón Bolívar, 2007, p. 17-45, que procura destacar o papel do autonomismo e do federalismo em Cádiz e, depois, em Madrid; para uma visão centrada no que os autores chamam de "transcendência" do fenômeno constitucional espanhol, veja-se: CHUST, Manuel \& FRASQUEST, Ivana. Las independencias en América. Madrid: Catarata, 2009, particularmente p. 59-65. Também: MARCHENA FERNÁNDEZ, Juan. ¿Obedientes al rey y desleales a sus ideas? Los liberales españoles ante la "reconquista" de América. In: MARCHENA F., Juan \& CHUST C., Manuel (Orgs.). Por la fuerzas de las armas: ejército e independencias en Iberoamerica. Castelló de la Plana: Publicaciones de la Universitat Jaume I, 2008. Para uma avaliação crítica da historiografia do "liberalismo" espanhol e seus desdobramentos na América, vide: BREÑA, Roberto. El primer liberalismo español y los procesos de emancipación de América, 1808-1824. Una revisión historiográfica del liberalismo hispánico. México: El Colegio de México, 2006.

${ }^{74}$ CHIARAMONTE, José Carlos. La cuestión de la soberanía en la génesis y constitución del Estado argentino. Revista Electrónica de Historia Constitucional, n 2, junho 2001.
} 
... povos limítrofes do Brasil haviam-se já erguido e lutavam para sacudir o jugo colonial e constituir-se em Nações livres; o exemplo era fascinante e contagioso; e já com temerária franqueza essas idéias e necessidades enunciavam-se em Pernambuco; nem faltava a inteligência, quando não alguma coisa de liga, a respeito, em outras províncias do Norte. ${ }^{75}$

Em outra ocasião, na biografia dedicada a José da Natividade Saldanha, Melo retomaria a mesma tese:

Já os povos contérminos ao Sul e ao Poente do Brasil derramavam em batalhas seu robusto sangue para sacudirem o jugo colonial e constituírem-se em Nações independentes e livres. O não acompanhá-los esta outra parte da América, o Brasil, em tão generosa e sublime empresa, seria uma prova indeclinável de seu atraso intelectual e moral, de seu contentamento ou vil frieza nos ferros da absoluta tirania embrutecedora. Livrou-a, porém, deste opróbrio a província de Pernambuco. ${ }^{76}$

Um documento citado pelo historiador Amaro Quintas e atribuído ao padre João Ribeiro - presidente da junta de governo eleita no Recife em março de 1817 - aduzia, numa missiva aos paraibanos, que "Pernambuco, Paraíba, Rio Grande e Ceará devem formar uma só República, devendo-se edificar uma cidade central para capital". Ademais, afirmava que "o levantamento de uma cidade central" era tarefa "essencial" da nova república, "e cumpria que esta capital fosse na província da Paraíba". Infelizmente, Quintas não se refere à fonte de sua citação. ${ }^{77}$

Republicanismo e federalismo caminhavam aí juntos, como na região do Rio da Prata, nos Estados Unidos da América ou nos cantões suíços. No entanto, no casamento entre federalismo e constitucionalismo ocorrido no âmbito das Cortes espanholas, o primeiro teria que se ver o monarquismo. ${ }^{78}$ Não seria diferente na América portuguesa, a partir de 1820, por ocasião do chamamento às Cortes de Lisboa. Laços

${ }^{75}$ MELO, Antônio Joaquim de. Biografia de Gervásio Pires Ferreira (v. 1). Recife: Editora Universitária, 1973, p. 24; MELO, Antônio Joaquim de. Biografia de José da Natividade Saldanha. Recife: Tipografia de Manoel Figueroa Faria \& Filho, 1895, p. 11-12.

${ }^{76}$ MELO, Antônio Joaquim de. Biografia de José da Natividade Saldanha. Recife: Tipografia de Manoel Figueroa Faria \& Filho, 1895, p. 11-12.

77 QUINTAS, Amaro. Agitação..., op. cit., p. 220; MOTA, C. G. Nordeste..., p. 55.

${ }^{78}$ A respeito da carga conceitual destes termos no mundo ibérico, ver várias valiosas contribuições em duas obras modelares: GOLDMAN, Noemi (ed.). Lenguaje y revolución. Conceptos políticos clave en el Río de la Plata, 1780-1850. Buenos Aires: Prometeo, 2008; e FERNÁNDEZ SEBASTIÁN, Javier (dir.). Diccionario político y social del mundo iberoamericano. Madrid: Fundación Carolina/Centro de Estudios Políticos y Constitucionales, 2009. 
de tipo federativo pareciam, contudo, mais pronunciados entre os deputados pernambucanos, como bem demonstrou a historiografia, e como bem atestam alguns documentos pouco suspeitos, a exemplo de uma avaliação da situação política pernambucana escrita pelo último governador colonial, Luís do Rego Barreto. Este escrevia ao rei D. João VI, em 20 de maio de 1821, informando que:

Tive a honra de expor a Vossa Majestade a 2 de abril do corrente que alguns demagogos levantaram depois do dia 26 de março uma voz de independência, não propriamente de uma separação absoluta, mas o seu fito era, a meu parecer, em um Governo Federal, deixando cada Capitania governar-se por si, e por o que eles chamavam Patrícios; este partido ia ganhando prosélitos; porque vigorava o ódio dos naturais aos Europeus, e foi abraçado por muitos que pretendiam empresas, considerações, etc. Coroavam-se estes fins com as aparentes pretensões de uma Junta Provisional, eleita pelo povo, mas corriam pelas mãos dos prosélitos do novo sistema listas dos que haviam de ser nomeados. ${ }^{79}$

"Governo Federal" e "Junta de Governo" eram expressões políticas e institucionais articuladas não nas tradições políticas norte-americanas, mas nas recentes experiências hispânicas, ainda mais propriamente nas hispano-americanas. E, com efeito, o juramento constitucional de D. João VI, realizado em fevereiro de 1821, premido pelas circunstâncias políticas que demarcavam os avanços liberais na Europa e na América portuguesa, forcejava pelo mesmo caminho. Afirmava o rei que:

Havendo tomado em consideração o termo do juramento que os eleitores paroquiais desta comarca, a instâncias e declaração unânime do povo dela, prestaram à constituição espanhola, e que fizeram subir à minha real presença, para ficar valendo interinamente a dita Constituição em que trabalharam as cortes atuais de Lisboa, em que eu houve por bem jurar com toda a minha corte, povo e tropa, no dia 26 de fevereiro do ano corrente; sou servido ordenar que de hoje em diante se fique estrita e literalmente observado neste reino do Brasil a mencionada constituição deliberada e decidida pelas Cortes de Lisboa. ${ }^{80}$

${ }^{79}$ Carta do governador da capitania de Pernambuco, Luís do Rego Barreto, ao rei D. João VI sobre ter tomado conhecimento do juramento à Constituição e informando as medidas tomadas para a eleição dos deputados da dita capitania que seguirão viagem ao Reino; as dificuldades de se proceder as eleições devido as distâncias das comarcas e os receios do povo; e informando ter reprimido todas as idéias propagadas nesta capitania acerca da instalação de um governo federal. AHU, cx. 281, doc. 19148. Recife, 20 de maio de 1821

${ }^{80}$ Vigência interina da Constituição Espanhola-Decreto de 21 de abril de 1821. BONAVIDES, Paulo \& AMARAL, Roberto. Textos políticos da história do Brasil. Brasília: Senado Federal, 2002, v. I. p. 493. 
Assim, uma nação - a portuguesa - arrogava-se soberana, mas mantinha sua monarquia, ao mesmo tempo em que adotava princípios constitucionais; por decorrência, rechaçava o republicanismo frequentemente associado à soberania popular. A convocação de uma representação nacional, a agregar representantes e interesses de partes politicamente diversas e, por vezes, dotadas de identidades coletivas próprias, requeria formas federativas de governo, de modo a dar conta da diversidade política e de interesses presentes à assembléia constituinte. Nada, portanto, mais hispânico; de certo modo, também, pernambucano, pois, nessa altura dos acontecimentos, os modelos políticos já tinham perdido suas eventuais feições de originalidade, compondo, uns com os outros, um espectro multifacetado.

E com isso, vemos que, ao final das contas, o equívoco em torno de Félix José Tavares Lira misturou verdade com verossimilhança, de modo a revelar uma situação paradigmática, pois, aqueles tempos não eram, definitivamente, afeitos a informações seguras; tampouco, a posições ou modelos políticos puros. É, pois, por esta via que há que se tentar entendê-los.

\section{Referências}

ALEXANDRE, Valentim. Os sentidos do império. Questão nacional e questão colonial na crise do antigo regime português. Porto: Afrontamento, 1993.

BARATA, Alexandre M. Francisco Álvaro da Silva Freire: negociante portuense e maçom. Texto apresentado no XI Encontro Regional de História. Rio de Janeiro, UERJ, 2004.

. Maçonaria, sociabilidade ilustrada e independência do Brasil (1790-1822). São Paulo/Juiz de Fora: Annablume/Editora UFJF/FAPESP, 2006.

BERBEL, Márcia Regina. A nação como artefato. Deputados do Brasil nas cortes portuguesas (1821-1822). São Paulo: Hucitec/FAPESP, 1999.

. Pátria e patriotas em Pernambuco (1817-1822): nação, identidade e vocabulário político. In: JANCSÓ, István (org.). Brasil: formação do Estado e da nação. São Paulo: HUCITEC, 2003.

Os apelos nacionais nas cortes constituintes de Lisboa (1821-22). In: MALERBA, Jurandir (Org.). A independência brasileira: novas dimensões. Rio de Janeiro: Editora FGV, 2006.

BERNARDES, Denis de Mendonça. O patriotismo constitucional. Pernambuco, 18201822. São Paulo/Recife: HUCITEC/Editora UFPE, 2006.

Pernambuco e o Império (1822-1824): sem constituição soberana não há união. In: JANCSÓ, István (org.). Brasil: formação do Estado e da nação. São Paulo/ HUCITEC, 2003.

BONAVIDES, Paulo \& AMARAL, Roberto. Textos politicos da história do Brasil. Brasília: Senado Federal, 2002. Vol. I. 
BREÑA, Roberto. El primer liberalismo español y los procesos de emancipación de América, 1808-1824. Una revisión historiográfica del liberalismo hispánico. México: El Colegio de México, 2006.

CHIARAMONTE, José Carlos. La cuestión de la soberanía en la génesis y constitución del Estado argentino. Revista Electrónica de Historia Constitucional, n. 2, junho 2001.

CHUST, Manuel; FRASQUET, Ivana. Las independencias en América. Madrid: Catarata, 2009.

COSTA, Francisco Augusto Pereira da. Anais pernambucanos. 2. ed. Recife: FUNDARPE, 1983.

Universal, 1882.

. Dicionário bibliográfico de pernambucanos célebres. Recife: Tipografia

DI MEGLIO, Gabriel. ¡Viva el bajo pueblo! La plebe urbana de Buenos Aires y la política entre la revolución de mayo y el rosismo. Buenos Aires: Prometeo, 2006.

ESDAILE, Charles. Las guerras de Napoleón. Una historia internacional, 1803-1815. Barcelona: Critica, 2009.

FERNANDES, Ana Cláudia. Revolução em pauta. O debate Correio Braziliense-Correo del Orinoco. São Paulo: FFLCH-USP, 2010. (Mestrado).

FERNÁNDEZ SEBASTIÁN, Javier (dir.). Diccionario político y social del mundo iberoamericano. Madrid: Fundación Carolina/Centro de Estudios Políticos y Constitucionales, 2009.

GARAVAGLIA, Juan Carlos. Os primórdios do processo de independência hispanoamericano. In: JANCSÓ, István (org.). Independência: história e historiografia. São Paulo: Hucitec/FAPESP, 2005.

GOLDMAN, Noemi (dir.). Revolución, república, confederación (1806-1852). Buenos Aires: Sudamericana, 1998.

(ed.). Lenguaje y revolución. Conceptos políticos clave en el Río de la Plata, 1780-1850. Buenos Aires: Prometeo, 2008.

GOMES, Geraldo. Engenho e arquitetura. Recife: FUNAJ/Massangana, 2006.

GONZÁLEZ BERNALDO, Pilar. Civilidad y politica en los orígenes de la Nación Argentina. Las sociabilidades en Buenos Aires, 1829-1862. Buenos Aires: FCE, 2001.

GRAFENSTEIN, Johanna Von. Corso y piratería en el Golfo-Caribe durante las guerras de independencia hispanoamericanas. In: AUGERON, M.; TRANCHANT, Mathias (orgs.). La violence et la mer dans l'espace atlantique (XII- $\mathrm{XIX}^{\mathrm{e}}$ siècle). Rennes: Presses Universitaires de Rennes, 2004.

GUERRA, François-Xavier. Modernidad e independencias. Ensayos sobre las revoluciones hispánicas. Madrid: Editorial Mapfre, 1992.

HALPERÍN DONGHI, Tulio. Tradición politica española e ideologia revolucionaria de Mayo. Buenos Aires: Eudeba, 1961.

LASSO, Marixa. Myths of harmony. Race and republicanism during the Age of Revolution, Colombia, 1795-1831. Pittsburgh: University Pittsburgh Press, 2007.

. Race War and Nation in Caribbean Gran Colombia, Cartagena, 1810-1832. The

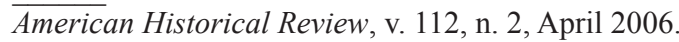


LEITE, Glacyra L. Pernambuco, 1817. Estrutura e comportamentos sociais. Recife: Editora Massagana, 1988.

LIMA, Manuel de Oliveira. Dom João VI no Brasil (1808-1821). Rio de Janeiro: Tipografia do Jornal do Commercio de Rodrigues \& C., 1908. 1997. O movimento da independência (1821-1822). Rio de Janeiro: Topbooks,

MACHADO, André R. de A. A quebra da mola real as sociedades: a crise política do Antigo Regime português na província do Grão-Pará (1821-1825). São Paulo: HUCITEC/FAPESP, 2010.

MARCHENA FERNÁNDEZ, Juan. ¿Obedientes al rey y desleales a sus ideas? Los liberales españoles ante la "reconquista" de América. In: MARCHENA F., Juan \& CHUST C., Manuel (Orgs.). Por la fuerzas de las armas: ejército e independencias en Iberoamerica. Castelló de la Plana: Publicaciones de la Universitat Jaume I, 2008.

MARTINS, Joaquim Dias. Os mártires pernambucanos vítimas da liberdade nas duas revoluções ensaiadas em 1710 e 1817. Recife: Tipografia de F. C. Lemos e Silva, 1853.

MELLO, Evaldo Cabral de. Frei Caneca ou a outra Independência. In: CANECA, Frei do Amor Divino. Frei do Amor Divino Caneca (organização e introdução de Evaldo Cabral de Mello). São Paulo: Editora 34, 2001.

. A outra independência. O federalismo pernambucano de 1817 a 1824 . Rio de Janeiro: Editora 34, 2004.

MELO, Antônio Joaquim de. Biografia de Gervásio Pires Ferreira. Recife: Editora Universitária, 1973.

Biografia de José da Natividade Saldanha. Recife: Tipografia de Manoel Figueroa Faria \& Filho, 1895.

MELO, Carlos Augusto. As histórias literárias do Cônego Fernandes Pinheiro e o cânone literário brasileiro. Terra roxa e outras terras - Revista de Estudos Literários, v. 9, 2007.

MOREL, Marco \& SOUZA, Françoise Jean. O poder da maçonaria. A história de uma sociedade secreta no Brasil. Rio de Janeiro: Nova Fronteira, 2008.

MOTA, Carlos G. Nordeste 1817: estruturas e argumentos. São Paulo: Perspectiva, 1972.

. O processo de independência no Nordeste. In: MOTA, Carlos G. (org.). 1822: dimensões. São Paulo: Perspectiva, 1972.

MÚNERA, Alfonso. El fracaso de la nación. Región, clase y raza en el Caribe colombiano (1717-1821). Bogotá: Editorial Planeta Colombiana, 2008.

MYERS, Jorge. A revolução de independência no Rio da Prata e as origens da nacionalidade argentina. In: PAMPLONA, Marco \& MÄDER, Maria Elisa (org.). Revoluções de independências e nacionalismos nas Américas 1: região do Prata e Chile. Rio de Janeiro: Paz e Terra, 2007.

PIMENTA, João Paulo G. O Brasil e a América espanhola. (Tese de Doutorado). São Paulo: FFLCH/USP, 2003.

. Estado e nação no fim dos impérios ibéricos no Prata (1808-1828). São Paulo: HUCITEC/FAPESP, 2002. 
PIMENTA, João Paulo G. A política hispano-americana e o império português (18101817): vocabulário político e conjuntura. In: JANCSÓ, István (org.). Brasil: formação do Estado e da nação. São Paulo: Hucitec/FAPESP, 2003.

PINHEIRO, J.C. Fernandes. Luiz do Rego e a posteridade - Estudo histórico sobre a revolução pernambucana de 1817. Revista do Instituto Histórico e Geográfico Brasileiro, v. 24,1861 .

QUINTAS, Amaro. A agitação republicana no Nordeste. In: HOLANDA, S. B. de. (dir.). História geral da civilização brasileira. São Paulo: Difusão Europeia do Livro, 1970. Tomo $2,1^{\circ} \mathrm{v}$.

RODRIGUES, José Honório. A inconfidência de 1801. In: Documentos Históricos. Rio de Janeiro: Biblioteca Nacional, 1955. Vol. CX.

RODRÍGUEZ O., Jaime E. El nacimiento de Hispanoamérica. Vicente Rocafuerte y el hispanoamericanismo, 1808-1832. Quito: Corporación Editora Nacional/Universidad Andina Simón Bolívar, 2007.

SCHWARTZ, Stuart B. Segredos internos. Engenhos e escravos na sociedade colonial (1550-1835). Trad. Laura Teixeira Motta. São Paulo/Brasília: Cia. das Letras/CNPq, 1988.

SILVA, Luiz Geraldo. Um projeto para a nação. Tensões e intenções políticas nas "Províncias do Norte". Revista de História, USP, v. 158, 2008.

. Pernambucanos, sois portugueses!' Natureza e modelos políticos das revoluções $\overline{\text { de } 1817}$ e 1824. Almanack Braziliense, v. 1, 2005.

O avesso da Independência: Pernambuco (1817-1824). In: MALERBA, Jurandir. (org.). A Independência brasileira. Novas dimensões. Rio de Janeiro: Editora FGV, 2006.

SOUSA, Maria Aparecida S. de. Bahia: de capitania a província, 1808-1823. São Paulo: FFLCH-USP, 2008. (Doutorado).

TAVARES, Francisco Muniz. História da revolução de Pernambuco em 1817. Revista e anotada por Oliveira Lima. Recife: Imprensa Industrial, 1917.

TEJERINA, Marcela. Luso-brasileños em el Buenos Aires virreinal. Trabajo, negócios e intereses em la Plaza naviera y comercial. Bahia Blanca: EDIUNS, 2004.

TERNAVASIO, Marcela. Gobernar la revolución. Poderes en disputa en el Rio de la Plata, 1810-1816. Buenos Aires: Siglo XXI, 2007.

VARNHAGEN, Francisco A. História geral do Brasil antes de sua separação e independência de Portugal. 9. ed. Revisão e notas de Rodolfo Garcia. São Paulo: Melhoramento, 1978. Tomo V.

VERDO, Geneviève. L'indépendance argentine entre cites et nation (1808-1821). Paris: Publications de la Sorbonne, 2006. 